\title{
Comparison of pre-germination treatments in Lupinus spp. and their effects on germination
} and related solutes

\author{
Edna Irene Bautista-Rodríguez', Luz del Carmen Lagunes-Espinoza*', \\ Francisco Marcelo Lara-Viveros², Mepivoseth Castelán-Estrada', Víctor \\ CONDE-MARTínez ${ }^{3}$
}

Botanical Sciences 95 (3): 577-590, 2017

DOI: $10.17129 /$ botsci.893

Copyright: (C) 2017 Bautista-Rodríguez et al. This is an open access article distributed under the terms of the Creative Commons Attribution License, which permits unrestricted use, distribution, and reproduction in any medium, provided the original author and source are credited.
1 Posgrado en Producción Agroalimentaria en el Trópico. Colegio de Postgraduados-Campus Tabasco. 86500 H. Cárdenas, Tabasco.

2 Universidad Politécnica de Francisco I. Madero. Francisco I. Madero, 42660 Tepatepec, Hgo. 3Colegio de Postgraduados-Campus Montecillo. 56230 Montecillo Edo. México.

*Corresponding author: lagunesc@colpos.mx

\section{Abstract}

Background: Physical dormancy in seeds of the genus Lupinus restricts their ecological or agricultural use. Hypothesis: This dormancy can be broken when seeds are subjected to physical and chemical pretreatments that increase germination, mobilize reserves and decrease ABA.

Studied species: Seeds of Lupinus exaltatus $(L e)$, L. campestris $(L c)$ and L. montanus $(L m)$ from Puebla, México. Methods: The following seven treatments, including a control, were applied: PG1 $=98 \% \mathrm{H}_{2} \mathrm{SO}_{4}$ for $15 \mathrm{~min}$, PG2 = wet sand at $80{ }^{\circ} \mathrm{C}$ for $5 \mathrm{~min}, \mathrm{PG} 3=$ wet sand at $35^{\circ} \mathrm{C}$ for $8 \mathrm{~h}$ and $16 \mathrm{~h}$ at $25^{\circ} \mathrm{C}$, PG4 = dry sand at $80{ }^{\circ} \mathrm{C}$ for $7 \mathrm{~min}, \mathrm{PG} 5=$ dry sand at $150{ }^{\circ} \mathrm{C}$ for $1 \mathrm{~min}, \mathrm{PG} 6=\mathrm{H}_{2} 0$ at $80^{\circ} \mathrm{C}$ for $1 \mathrm{~min}, \mathrm{Control}=$ untreated seeds. On days $0,3,5,10$ and 15 after seeding, we evaluated the percentage and rate of germination (GP and GR, respectively) and biochemical changes.

Results: PG6 produced a higher GP in Le (41\%) and Lc (69\%), and PG1 produced a higher GP in Lm (37\%). In all three species, the highest GR was obtained with PG1 $\left(1.95,2.27\right.$ and 2.22 day $^{-1}$ seeds, respectively). PG6 increased the protein concentration (53, 17, and $43 \%$ for $L e, L c$ and $L m$, respectively), amino acids (19, 44 and $31 \%$, respectively), reducing sugars (63, 18 and $96 \%$, respectively) and polyphenols $(32,55$ and $75 \%$, respectively) but decreased soluble sugars (22, 29 and $23 \%$, respectively) and ABA relative to the control. Although only the correlation between the GP and amino acid content was significant and positive, and the correlation between GP, GR and soluble sugars was significant and negative.

Conclusions: The effect of pre-germination treatments on germination was species-specific. The pretreatment with $\mathrm{H}_{2} \mathrm{O}$ at $80{ }^{\circ} \mathrm{C}$ for 1 min increased germination and mobilized the seed's reserves in the process.

Key words: Lupinus, physical dormancy, germination, protein, sugars.

\section{Resumen}

Antecedentes: La latencia física en semillas del género Lupinus restringe su uso ecológico o agronómico.

Hipótesis: Esta latencia puede liberarse al aplicarles pre-tratamientos físicos y químicos, lo que incrementa la germinación, moviliza reservas y disminuye el ABA.

Especie en estudio: Semillas de Lupinus exaltatus (Le), L. campestris ( $L c$ ) y L. montanus ( $L m$ ) del estado de Puebla, México.

Métodos: Se les aplicaron siete tratamientos, incluyendo un testigo: PG1 $=\mathrm{H}_{2} \mathrm{SO}_{4} 98 \% 15 \mathrm{~min}, \mathrm{PG} 2=$ Arena húmeda $80^{\circ} \mathrm{C} 5 \mathrm{~min}, \mathrm{PG} 3=35^{\circ} \mathrm{C} 8 \mathrm{~h}, 16 \mathrm{~h} 25^{\circ} \mathrm{C}, \mathrm{PG} 4=80^{\circ} \mathrm{C} 7 \mathrm{~min}, \mathrm{PG} 5=150^{\circ} \mathrm{C} 1 \mathrm{~min}, \mathrm{PG} 6=\mathrm{H}_{2} 080^{\circ} \mathrm{C}$ 1 min, Testigo = semillas no tratadas. A los 0,3, 5, 10 y 15 días después de siembra, evaluamos el porcentaje, velocidad de germinación (PG, VG) y cambios bioquímicos.

Resultados: El PG6 promovió mayor PG en $L e$ (41 \%) y Lc (69 \%), y el PG1 en $L m$ (37\%). En las tres especies, la mayor VG fue con el PG1 (1.95, 2.27 y 2.22 semillas día $^{-1}$, respectivamente). Con PG6, se observó un incremento en concentración de proteína (53,17, $43 \%$ para $L e, L c$ y $L m$, respectivamente), aminoácidos (19, 44 y $31 \%$ ), azúcares reductores $(63,18$ y $96 \%)$ y polifenoles $(32,55$ y $75 \%)$ pero disminuyeron los azúcares solubles $(22,29$ y $23 \%$ ) y ABA respecto al control. Aunque solo la correlación entre PG y aminoácidos fue significativa y positiva y entre PG, VG y azúcares solubles es significativa y negativa.

Conclusiones: Entre especies, el efecto de los tratamientos pre-germinativos sobre la germinación fue diferencial. El uso de $\mathrm{H}_{2} 080^{\circ} \mathrm{C} 1 \mathrm{~min}$ incrementó germinación y movilizó las reservas durante el proceso.

Palabras clave: Lupinus, latencia física, germinación, proteína, azúcares. 
everal species of seeds undergo physical dormancy caused by a testa that prevents water from permeating to the embryo (Baskin 2003) as the result of one or two layers of palisade cells (Baskin \& Baskin 2004). Seeds of different species within the Fabaceae family such as $\mathrm{Lu}$ pinus spp. exhibit this type of dormancy (Ali et al. 2011). Several methods exist for breaking the physical dormancy of hard-testa seeds. These methods are generally classified as physical (mechanical scarification, temperature alternation and shock, among others), chemical (acid scarification and soaking in alkaline solutions) and biological (use of enzymes or fungi) (Baskin \& Baskin 2014). These methods accelerate germination because they permit water permeability and gas exchange by wearing down or fracturing the testa (Qihe et al. 2006). Different methods have been tested to break the dormancy of seeds from the Lupinus genus; the effects vary depending on the species and the environment where the seed developed. In Lupinus exaltatus, which comes from areas prone to fires within the state of Jalisco, treatment with a temperature of $150{ }^{\circ} \mathrm{C}$, simulating forest fire, breaks physical dormancy and increases the germination percentages up to $92 \%$ (Zuloaga-Aguilar et al. 2011). High temperatures inhibit the germination of L. polyphyllus, L. lepidus and L. albicaulis seeds, but alternating cold temperatures, and pre-germination treatments that included moist heat increased germination by $>50 \%$ (Elliott et al. 2011). Scarification with sulfuric acid for 15 min has increased the germination of L. montanus seeds, but possible intraspecific variation exists. A germination percentage of $62.5 \%$ was achieved for seeds from La Joya, Mexico (Hernández-Ferretiz et al. 2008), whereas $100 \%$ of seeds from the Cumbres del Ajusco National Park germinated (Acosta-Percástegui \& Rodríguez-Trejo 2005).

When dormancy is broken and water and gases can reach the embryo, the metabolism of reserve compounds is reactivated, hydrolyzing or synthesizing new compounds (Bewley et al. 2013). This mobilization of seed reserves during the first phase of germination is an essential process for embryo development and the later formation of seedlings (Satyanarayana et al. 2011). Changes in the reserve compounds have been observed when Cyclocarya paliurus seeds are released from dormancy by scarification. In this species, starch decreased by $45 \%$, crude protein by $45 \%$ and lipid by $11 \%$, but soluble sugars increased by $101.5 \%$ (Shen-zou \& Jiayuan 2007). With Oryza sativa seeds, a hydrothermal treatment at $50{ }^{\circ} \mathrm{C}$ for $15 \mathrm{~min}$ increased not only the percent germination but also the respiration rate and $\alpha$-amylase activity (Tung $\&$ Serrano 2011).

Although it is documented that the process of releasing physical dormancy involves changes in the seed reserves when germination is promoted and the application of scarification treatments can modify these changes, there are few studies that document the changes in Lupinus seeds. For this reason, the objectives of this study were as follows: a) to evaluate the effect of different scarification treatments on the rate and percent germination of Lupinus spp. seeds and b) to determine changes in the contents of protein, soluble sugars, reducing sugars, amino acids, polyphenols and abscisic acid during germination after applying pre-germination treatments.

\section{Materials and methods}

Biological material. Mature seeds of Lupinus campestris Schltdl. \& Cham. (Lc) and Lupinus exaltatus Zucc (Le) were collected on September 20, 2014, at 2,866 and 3,066 m asl, respectively, in the region of the Serdán and Libres Valleys, Puebla, Mexico. Seeds of Lupinus montanus Kunth $(\mathrm{Lm})$ were collected on November 8,2[R1]014, at 3,442 $\mathrm{m}$ asl in the same region. Healthy seeds were selected and conserved at $4{ }^{\circ} \mathrm{C}$ for approximately two months before analysis. A topographic test using tetrazolium chloride was performed on the seeds prior to analysis. The percent viability was $93.3 \%$ for L. exaltatus, $90.6 \%$ for L campestris and $96.6 \%$ for $L$. montanus.

Pre-germination treatments. Before applying the pre-germination treatments, triplicate lots of 50 seeds of each species were disinfected with a $3 \%$ sodium hypochlorite for 2 min (except treatment PG1) and washed with sterile distilled water. The pre-germination treatments were as follows: PG1, immersion in $98 \% \mathrm{H}_{2} \mathrm{SO}_{4}$ for $15 \mathrm{~min}$; PG2, immersion in sterile wet sand at $80{ }^{\circ} \mathrm{C}$ for $5 \mathrm{~min}$; PG3, alternating temperatures of $35^{\circ} \mathrm{C}$ for $8 \mathrm{~h}$ followed by $16 \mathrm{~h}$ at $25^{\circ} \mathrm{C}$ in sterile wet sand; PG4, dry heat at $80^{\circ} \mathrm{C}$ for $7 \mathrm{~min}$ in sterile sand; PG5, dry heat at $150{ }^{\circ} \mathrm{C}$ for 1 
min in sterile sand; and PG6, immersion in $\mathrm{H}_{2} \mathrm{O}$ at $80^{\circ} \mathrm{C}$ for $1 \mathrm{~min}$. A control was included with untreated seeds.

After each pretreatment, the seeds were placed in plastic Petri dishes between layers of sterile absorbent paper in a growing chamber (Thermo Scientific, model 818 , USA) at $20^{\circ} \mathrm{C}$ with white LED light for $12 \mathrm{~h}$ followed by a $12 \mathrm{~h}$ dark period at $15^{\circ} \mathrm{C}$. For each species, 50 seeds were placed in the Petri dishes in triplicate. The percent germination (GP) and germination rate (GR) were assessed at 3, 5, 10 and 15 days after seeding (das). For GP, a seed was considered germinated when the radicle was $\geq 2 \mathrm{~mm}$ long. GR was determined using the formula GR $=\Sigma$ $(\mathrm{NGSi}) / t$, where NGSi is the number of germinated seeds on day $i$ and $t$ is the time from sowing to germination of the last seed. During germination, the seeds were watered daily with room temperature sterile distilled water. Following each germination period, the seeds were dried in a forced air oven at $50{ }^{\circ} \mathrm{C}$ for $48 \mathrm{~h}$ (Tonguc et al. 2012). They were then ground in a mortar and de-fatted for $2 \mathrm{~h}$ with $95 \%$ hexane in a 1:10 flour/hexane mixture $(\mathrm{w} / \mathrm{v})$ with constant shaking at $280 \mathrm{rpm}$ at $4{ }^{\circ} \mathrm{C}$. The mixture was centrifuged at $10,000 \mathrm{rpm}$ for $10 \mathrm{~min}$ at $4{ }^{\circ} \mathrm{C}$. The supernatant was decanted and the remaining fat-free precipitate was left to dry at room temperature until the solvent had completely evaporated. The dried precipitate was stored until use at $4{ }^{\circ} \mathrm{C}$.

Biochemical analyses. Biochemical analyses were conducted 0,3,5 10 and 15 das in the two pre-germination treatments that significantly increased germination (PG1 and PG6) and the control, using all of the seeds per treatment and replication. All of the analyses were performed in triplicate and the results were expressed in $\mathrm{mg} \mathrm{g}^{-1}$.

Soluble protein. The total protein content was estimated using the method of Lowry et al. (1951). To $100 \mathrm{mg}$ of previously de-fatted flour, $2.5 \mathrm{~mL}$ of a solution of $0.3 \mathrm{~mol} \mathrm{~L}^{-1}$ tris- $\mathrm{HCL}, \mathrm{pH} 8.0$, and $0.01 \mathrm{~mol} \mathrm{~L}^{-1} \beta$-mercaptoethanol was added. The mixture was vortexed and left to incubate for $1 \mathrm{~h}$ with shaking every $10 \mathrm{~min}$. It was then centrifuged at room temperature for $20 \mathrm{~min}$ at $1,100 \times \mathrm{g}$, and the supernatant was collected to determine the protein content (Sussulini et al. 2007). Of the collected and diluted (1:4) supernatant, $0.02 \mathrm{~mL}$ was taken and $0.7 \mathrm{~mL}$ Lowry solution was added; the mixture was left to incubate in darkness for $20 \mathrm{~min}$. After incubation, $0.1 \mathrm{~mL} 2 \mathrm{~N}$ Folin Ciocalteu reagent was added and the mixture was left to incubate for $30 \mathrm{~min}$ in darkness. The protein concentration was determined based on a $1 \mathrm{mg} \mathrm{mL}^{-1}$ standard solution of bovine serum albumin (BSA). The absorbance was measured at $750 \mathrm{~nm}$.

Total soluble sugars, reducing sugars and amino acids. For the extraction, $200 \mathrm{mg}$ of previously de-fatted dry sample of each species and treatment was weighed in triplicate. Three milliliters of absolute ethanol was added to each sample, which was then placed in a water bath at $70{ }^{\circ} \mathrm{C}$ for $5 \mathrm{~min}$. After incubating in the water bath, the supernatant (extract) was recovered in a $50 \mathrm{~mL}$ Erlenmeyer flask. This process was repeated four times. The extract was dried in a forced-air oven at $70{ }^{\circ} \mathrm{C}$ until completely dry. It was then re-suspended in $1 \mathrm{~mL}$ distilled water and stored at $-20{ }^{\circ} \mathrm{C}$ until analysis.

Total soluble sugars. The total soluble sugars were determined with the Somogy (1952) method using a $100 \mu \mathrm{L}$ sample with $300 \mu \mathrm{L}$ distilled water and $3 \mathrm{~mL}$ Anthrone. This mixture was vortexed and left to cool on ice for $5 \mathrm{~min}$. It was then placed in a water bath at $100{ }^{\circ} \mathrm{C}$ for $10 \mathrm{~min}$. The tubes were then left to cool at room temperature. The total soluble sugars concentration was determined based on a $2.5 \mathrm{mg} \mathrm{mL}^{-1}$ standard solution of glucose. The absorbance was read at $625 \mathrm{~nm}$.

Reducing sugars. To $0.5 \mathrm{~mL}$ of the sample, $1.5 \mathrm{~mL}$ distilled water and $1 \mathrm{~mL}$ copper tartrate alkaline solution was added. The samples were placed in a water bath at $100{ }^{\circ} \mathrm{C}$ for $10 \mathrm{~min}$ and then left to cool at room temperature. One $\mathrm{mL}$ arsenomolybdate reagent was added, and then 6 $\mathrm{mL}$ distilled water was added. For the calibration curve, concentrations from 0 to $0.25 \mathrm{mg} \mathrm{mL}^{-1}$ were prepared from a standard solution of $2.5 \mathrm{mg} \mathrm{mL}^{-1}$ glucose. The absorbance was read at $620 \mathrm{~nm}$.

Total amino acids. The amino acid content was determined using the method of Yemm \& Cocking (1995). We used $0.1 \mathrm{~mL}$ of the sample, added distilled water to a $1 \mathrm{~mL}$ volume and added 1 
$\mathrm{mL}$ of the reagent ninhydrin. The resulting solution was vortexed and then placed in a water bath at $100{ }^{\circ} \mathrm{C}$ for $15 \mathrm{~min}$, after which the solution [R2] was placed in cold water and $5 \mathrm{~mL} 80 \%$ ethanol was added and left to incubate at room temperature for $10 \mathrm{~min}$. For the calibration curve, concentrations of 0 to $100 \mu \mathrm{g} \mathrm{mL}^{-1}$ were prepared from a standard solution of $100 \mu \mathrm{g} \mathrm{mL}^{-1}$ leucine. The absorbance was read at $570 \mathrm{~nm}$.

Total polyphenols. Of the dry de-fatted sample, $250 \mathrm{mg}$ was weighed in triplicate. The polyphenols were extracted by shaking (vortexed for $1 \mathrm{~min}$ ) with $1 \mathrm{~mL} 80 \%$ methanol. The samples were then placed in a water bath at $50{ }^{\circ} \mathrm{C}$ for $15 \mathrm{~min}$ and centrifuged at $10,956 \times \mathrm{g}$ for $15 \mathrm{~min}$. The supernatant was recovered and the residue was again washed and mixed with $0.5 \mathrm{~mL} 100 \%$ methanol. Both supernatants were recovered and the volume was increased to $1.5 \mathrm{~mL}$ with distilled water and stored at $-20{ }^{\circ} \mathrm{C}$ protected from light. For quantification, $1.5 \mathrm{~mL}$ distilled water, $0.1 \mathrm{~mL} 50 \%$ Folin-Denis reagent and $0.2 \mathrm{~mL} 15 \%$ anhydrous sodium carbonate were added to $0.2 \mathrm{~mL}$ of the extract. These were vortexed and left to incubate for $30 \mathrm{~min}$ in darkness. For the calibration curve, concentrations of 0 to $100 \mu \mathrm{g} \mathrm{mL}^{-1}$ were prepared from a stock solution of $100 \mu \mathrm{g} \mathrm{mL}^{-1}$ gallic acid, which was used to make standard solutions. The absorbance was read at $765 \mathrm{~nm}$.

Abscisic acid (ABA). The concentration of abscisic acid was determined following the methods of Khadri et al. (2006) and Kishwar et al. (2011). The analysis was conducted with untreated seeds, with treated seeds immediately after the application of $80{ }^{\circ} \mathrm{C}$ water for $1 \mathrm{~min}$, and with treated seeds of more than 30 das. From these samples, $0.5 \mathrm{~g}$ of fresh material was macerated with $5 \mathrm{~mL}$ of an extraction solvent (80\% methanol and $10 \mathrm{mg} \mathrm{L}^{-1}$ butylatehydroxitoluene) and incubated at $4^{\circ} \mathrm{C}$ for $1 \mathrm{~h}$. After incubation, the mixture was centrifuged at $10,956 \times \mathrm{g}$ for $15 \mathrm{~min}$. The supernatant was collected and two additional extractions were made of the precipitate with $1 \mathrm{~mL}$ extraction solvent. The three supernatants were aggregated and $30 \mathrm{mg}$ polyvinyl-polypyrrolidone (PVPP) was added to eliminate plant pigments and other non-polar compounds that might interfere with the immunoassay.

The supernatant obtained was concentrated to dryness [R3] and re-suspended in $0.5 \mathrm{~mL} 25$ $\mathrm{mM}$ Tris- $\mathrm{HCl}$ buffer, $\mathrm{pH}$ 7.5, which contained $100 \mathrm{mM} \mathrm{NaCl}$ and $1 \mathrm{mM}$ magnesium chloride. ABA was quantified by immunoassay (ELISA) using the PGR-1 detection kit specific for this hormone (Sigma PGR1-1KT). Aliquots of $0.1 \mathrm{~mL}$ sample and $0.1 \mathrm{~mL}$ tracer solution were added to each well and incubated at $4{ }^{\circ} \mathrm{C}$ for $3 \mathrm{~h}$. During incubation, the ABA of the sample competes with the tracer molecule bound to the enzyme alkaline phosphatase because it binds to the ABA-specific monoclonal antibodies fixed on the ELISA plate.After incubation, the plates were washed twice with $0.1 \mathrm{~mL}$ PBS Tween washing solution, $0.2 \mathrm{~mL}$ substrate solution (paranitrophenyl phosphate) was added, and the plates were incubated at $37^{\circ} \mathrm{C}$ for $60 \mathrm{~min}$ to produce the enzyme reaction. The absorbance was read at $405 \mathrm{~nm}$ with an ELISA plate reader. Quantification of ABA was based on an ABA standard curve (0-1,000 pmol mL-1).

Statistical analysis. GP data were arcsine square root transformed (Elliott et al. 2011) to obtain an approximate normal distribution of the percentages. These data, together with GR and biochemical analyses, were subjected, by species, to an analysis of variance in a completely randomized design in a factorial array. The first factor consisted of the eight pre-germination treatments and the second factor consisted of the four time intervals $(0,3,5,10,15$ das $)$ and their interactions (Treatment*Time). A Tukey test was used to distinguish differences among treatments, and Pearson correlations were performed using SAS statistical software (SAS, 2010).

\section{Results}

Percent germination and germination rate (GP and GR). The GP of the three Lupinus species was significantly affected $(P<0.05)$ by the application of the pre-germination treatments (Table 1). $\mathrm{PG} 2$ and PG6 surpassed the control (7 \% GP) for L. exaltatus. The treatment with $\mathrm{H}_{2} \mathrm{O}$ at $80{ }^{\circ} \mathrm{C}$ for 1 min (PG6) was the most effective treatment (41\% GP) $(P<0.05)$, followed by the treatment with $98 \% \mathrm{H}_{2} \mathrm{SO}_{4}$ for $15 \mathrm{~min}$ (34\% GP), surpassing the control by $33 \%$ and $27 \%$, respectively. For treatment PG6, the greatest increase in germination was observed on days 10 
Table 1. Effect of pre-germination treatments on percent germination of $L$. exaltatus, $L$. campestris and $L$. montanus seeds at different times during the germination process (3, 5, 10 and 15 days).

\begin{tabular}{cccccccc} 
Species, das & \multicolumn{7}{c}{ Germination (\%) } \\
& Control & PG1 & PG2 & PG3 & PG4 & PG5 & PG6 \\
\hline L. exaltatus & & & & & & & \\
3 & $4.82 \mathrm{~d}$ & $23.4 \mathrm{bc}$ & $2.82 \mathrm{~d}$ & $2.94 \mathrm{~d}$ & $0 \mathrm{~d}$ & $0 \mathrm{~d}$ & $5.33 \mathrm{~d}$ \\
5 & $7.36 \mathrm{~d}$ & $28.4 \mathrm{~b}$ & $4.56 \mathrm{~d}$ & $3.34 \mathrm{~d}$ & $0 \mathrm{~d}$ & $0 \mathrm{~d}$ & $5.33 \mathrm{~d}$ \\
10 & $7.76 \mathrm{~d}$ & $31.4 \mathrm{ab}$ & $7.36 \mathrm{~d}$ & $3.34 \mathrm{~d}$ & $0.4 \mathrm{~d}$ & $0 \mathrm{~d}$ & $22.67 \mathrm{bc}$ \\
15 & $7.76 \mathrm{~d}$ & $34.4 \mathrm{ab}$ & $12.3 \mathrm{~cd}$ & $4.28 \mathrm{~d}$ & $5.79 \mathrm{~d}$ & $0 \mathrm{~d}$ & $41.33 \mathrm{a}$ \\
\hline L. campestris & & & & & & & \\
3 & $3.2 \mathrm{f}$ & $25.51 \mathrm{~cd}$ & $2.58 \mathrm{f}$ & $3.91 \mathrm{f}$ & $3.85 \mathrm{f}$ & $1.6 \mathrm{f}$ & $4 \mathrm{f}$ \\
5 & $4.22 \mathrm{f}$ & $27.29 \mathrm{~cd}$ & $3.38 \mathrm{f}$ & $4.31 \mathrm{f}$ & $6.36 \mathrm{f}$ & $2 \mathrm{f}$ & $4 \mathrm{f}$ \\
10 & $4.62 \mathrm{f}$ & $31.27 \mathrm{~cd}$ & $8.14 \mathrm{f}$ & $5.43 \mathrm{f}$ & $8.21 \mathrm{f}$ & $3.2 \mathrm{f}$ & $62.67 \mathrm{a}$ \\
15 & $4.62 \mathrm{f}$ & $34.05 \mathrm{c}$ & $22.39 \mathrm{cde}$ & $6.5 \mathrm{f}$ & $11.26 \mathrm{ef}$ & $21.5 \mathrm{de}$ & $69.33 \mathrm{a}$ \\
\hline L. montanus & & & & & & & \\
3 & $6 \mathrm{c}$ & $25.06 \mathrm{ab}$ & $2.33 \mathrm{c}$ & $1.5 \mathrm{c}$ & $4.59 \mathrm{c}$ & $1 \mathrm{c}$ & $5.33 \mathrm{c}$ \\
5 & $7.33 \mathrm{c}$ & $27.56 \mathrm{a}$ & $2.33 \mathrm{c}$ & $1.5 \mathrm{c}$ & $4.59 \mathrm{c}$ & $1.5 \mathrm{c}$ & $5.33 \mathrm{c}$ \\
10 & $7.33 \mathrm{c}$ & $32.98 \mathrm{a}$ & $3.67 \mathrm{c}$ & $1.5 \mathrm{c}$ & $5.59 \mathrm{c}$ & $3 \mathrm{c}$ & $30.67 \mathrm{a}$ \\
15 & $7.33 \mathrm{c}$ & $37.33 \mathrm{a}$ & $12.83 \mathrm{bc}$ & $2 \mathrm{c}$ & $9.67 \mathrm{c}$ & $10.5 \mathrm{c}$ & $36 \mathrm{a}$
\end{tabular}

Control: untreated seeds; PG1: $\mathrm{H}_{2} \mathrm{SO}_{4}$ for $15 \mathrm{~min}$; PG2: $\mathrm{H}_{2} 0$ at $80{ }^{\circ} \mathrm{C}$ for 5 min; PG3: wet sand at $35{ }^{\circ} \mathrm{C}$ for $8 \mathrm{~h}$ followed by $16 \mathrm{~h}$ at $25^{\circ} \mathrm{C}$; PG4: dry sand at $80^{\circ} \mathrm{C}$ for $7 \mathrm{~min}$; PG5: sand at $150{ }^{\circ} \mathrm{C}$ for $1 \mathrm{~min}$; PG6: water at $80{ }^{\circ} \mathrm{C}$ for $1 \mathrm{~min}$. das $=$ days after seeding. Different letters within species indicate significant differences $(P<0.05)$.

and 15, whereas with PG1, germination began rapidly in the first days after seeding. Treatment PG5 $\left(150{ }^{\circ} \mathrm{C}\right.$ for $1 \mathrm{~min}$ ) inhibited germination in this species. A similar effect was observed on the GP of L. campestris seeds, for which the PG1, PG2, PG5 and PG6 treatments surpassed the control. For this species, PG6 was the best treatment, increasing the GP to $69 \%$. The greatest increase in germination for this treatment occurred at 10 das. For L. montanus, the PG1 and PG6 treatments surpassed the control, but there was no significant difference between them $(P<0.05)$. The effect of the pre-germination treatments on the average GR can be seen in Figure 1 . In the

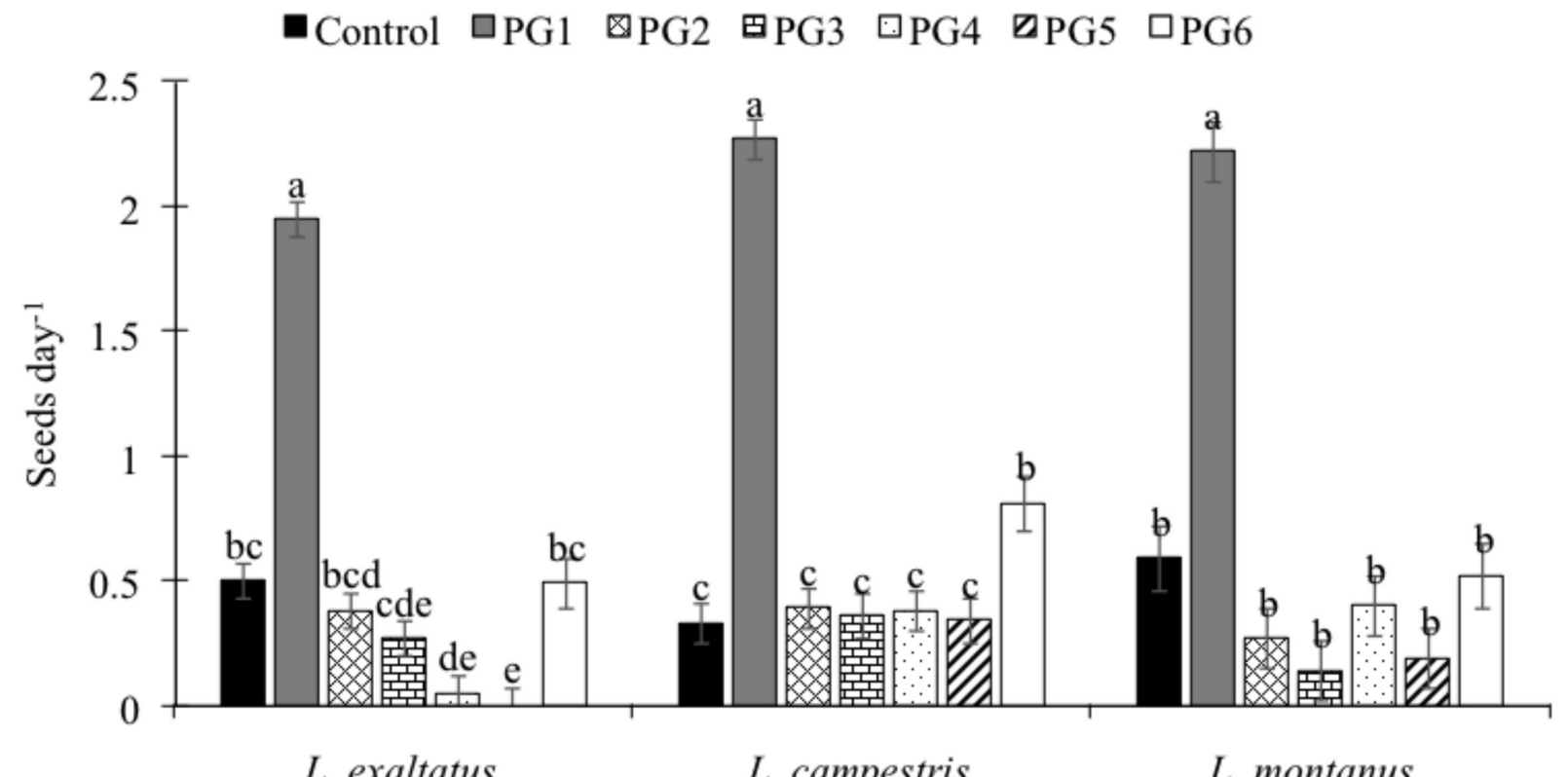

Figure 1. Effect of pre-germination treatments on germination rate (GR) of Lupinus seeds. Control: untreated seeds; PG1: $\mathrm{H}_{2} \mathrm{SO}_{4}$ for 15 min; PG2: $\mathrm{H}_{2} 0$ at $80{ }^{\circ} \mathrm{C}$ for $5 \mathrm{~min}$; PG3: wet sand at $35^{\circ} \mathrm{C}$ for $8 \mathrm{~h}$ followed by $16 \mathrm{~h}$ at $25^{\circ} \mathrm{C}$; PG4: dry sand at $80{ }^{\circ} \mathrm{C}$ for 7 min; PG5: sand at $150{ }^{\circ} \mathrm{C}$ for $1 \mathrm{~min}$; PG6: water at $80^{\circ} \mathrm{C}$ for $1 \mathrm{~min}$. Different letters within treatments indicate significant differences $(P<0.05)$. 


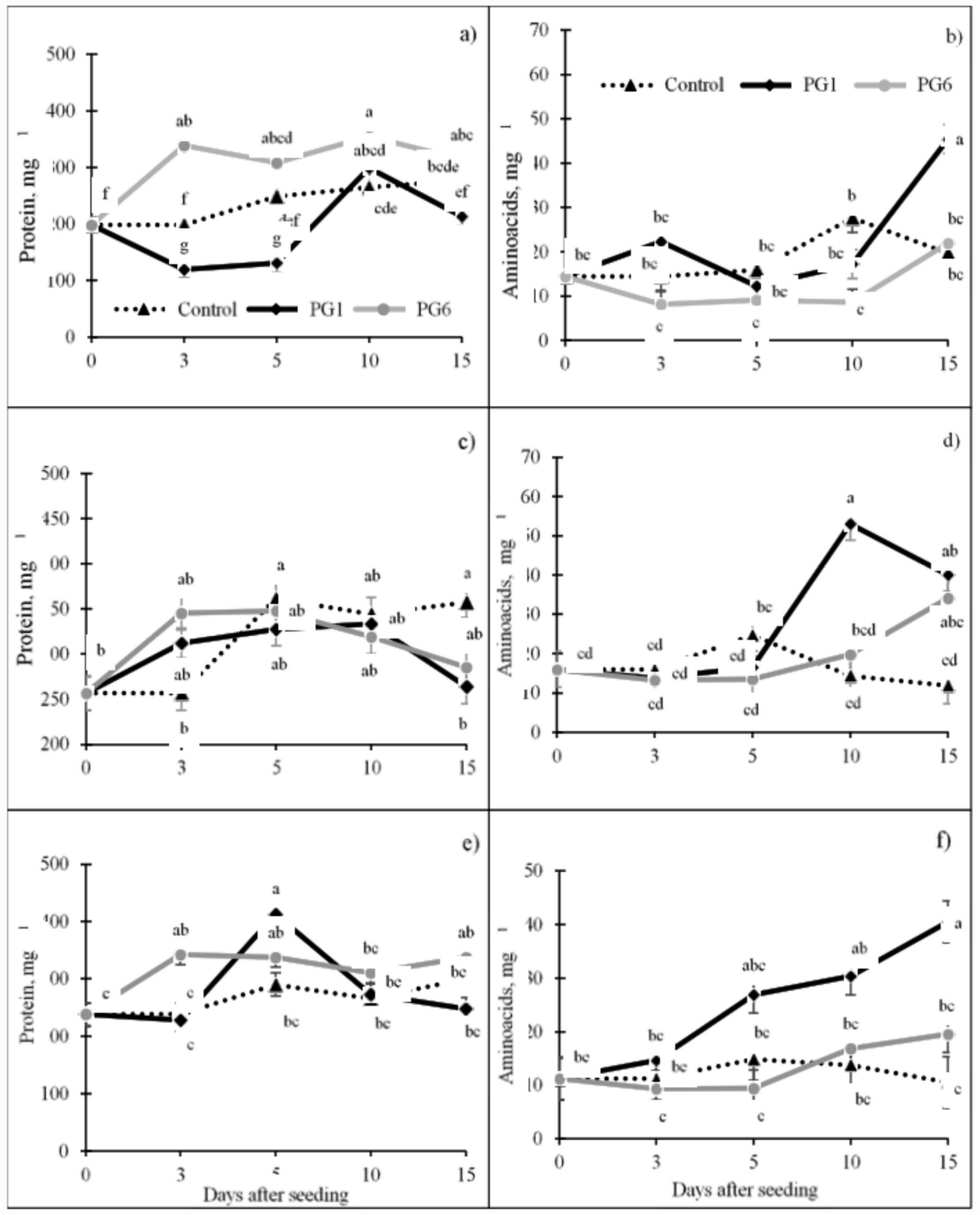

Figure 2. Effect of pre-germination treatments on the concentrations of soluble proteins and amino acids in seeds of $L$. exaltatus (a, b), $L$.

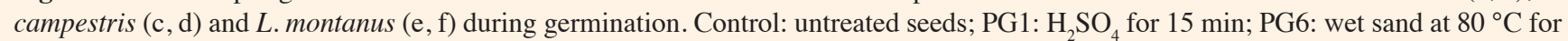
$1 \mathrm{~min}$. Different letters within treatments indicate significant differences $(P<0.05)$. 
Table 2. Pearson's correlations between percent germination (GP) and germination rate (GR, seeds day $\left.{ }^{-1}\right)$, and biochemical traits in L. exaltatus, L. campestris and L. montanus seeds, by effect of germination pretreatments.

\begin{tabular}{|c|c|c|c|c|c|}
\hline & Protein & Amino acids & $\begin{array}{l}\text { Total soluble } \\
\text { sugars }\end{array}$ & $\begin{array}{l}\text { Reducing } \\
\text { sugars }\end{array}$ & $\begin{array}{l}\text { Total } \\
\text { polyphenols }\end{array}$ \\
\hline \multicolumn{6}{|c|}{ L. exaltatus, mg g-1 } \\
\hline GP & -0.14 & $0.38^{*}$ & $-0.45^{* * *}$ & -0.002 & 0.10 \\
\hline GR & $-0.44 * * *$ & 0.08 & $-0.29 * * *$ & -0.06 & -0.05 \\
\hline \multicolumn{6}{|c|}{ L. campestris, $\mathrm{mg} \mathrm{g}^{-1}$} \\
\hline GP & -0.25 & $0.60^{* * *}$ & $-0.40^{* *}$ & $-0.53^{* * *}$ & $0.29 *$ \\
\hline GR & -0.06 & 0.06 & $-0.42^{* *}$ & $-0.63^{* * *}$ & -0.05 \\
\hline \multicolumn{6}{|c|}{ L. montanus, $\mathrm{mg} \mathrm{g}^{-1}$} \\
\hline GP & 0.15 & $0.72^{* * *}$ & $-0.31 *$ & -0.02 & $0.72^{* * *}$ \\
\hline GR & 0.01 & $0.34^{*}$ & $-0.31^{*}$ & $-0.40^{*}$ & 0.43 \\
\hline
\end{tabular}

three species, the treatment with concentrated sulfuric acid (PG1) showed the greatest increase in the average GR relative to the control, followed by PG6.

Soluble protein. During germination, both increases and decreases in the concentration of protein were observed among species. The treatment with water at $80^{\circ} \mathrm{C}$ for $1 \mathrm{~min}(\mathrm{PG} 6)$ increased the protein concentration by $13 \%$ relative to the control in L. exaltatus (Figure 2a), and the sulfuric acid treatment (PG1) decreased protein on days 3 and 5 by 239 and $47 \%$, respectively, relative to the control, but the protein concentration increased gradually thereafter. In L. campestris (Figure 2c), the treatment with $98 \% \mathrm{H}_{2} \mathrm{SO}_{4}$ for $15 \mathrm{~min}$ (PG1) had the opposite effect on protein mobilization, beginning with an increase on day 3 (21 and $24 \%)$ relative to the control and decreasing on day 15 (-26 and $-20 \%)$. In L. montanus seeds (Figure 2e), the protein concentration increased significantly with both PG1 and PG6, similar to L. exaltatus. However, the Pearson's coefficients did not show a significant correlation between soluble protein concentration and PG or GR in the species under study, with the exception of GR in L. exaltatus (Table 2).

Amino acids (AA). A highly significant, positive relation was observed between the AA concentration and the GP for the three species under study (Table 2). During germination, the concentration of AA increased in L. exaltatus (Figure 2b) under PG1 $\left(22.3 \mathrm{mg} \mathrm{g}^{-1}\right)$ relative to the control and then decreased between 5 and 10 das. On day 15, the AA concentration increased and surpassed the control by $130 \%$. The AA concentration in treatment PG6 was the lowest of all the treatments throughout the period of germination. In L. campestris seeds (Figure 2d), the AA concentration decreased slowly from 3 to 5 das (43\%) relative to day 0 in PG1 and PG6. The highest level of synthesis was observed at 10 and 15 das, surpassing the control by 239 and $189 \%$, respectively. In PG1 with L. montanus seeds (Figure 2f), the average amino acid concentration increased with germination time, surpassing the control by $283 \%$ at 15 das.

Total soluble sugars (TSS). A highly significant, negative relation was observed between TSS concentrations and both GP and GR in the species under study (Table 2). The highest average concentration of TSS was observed in the control $\left(381.47 \mathrm{mg} \mathrm{g}^{-1}\right)$. In contrast, the two pre-germination treatments exhibited a decrease in the TSS concentration relative to the control. On average, the greatest decrease in these sugars occurred at 3 das (47\%, relative to day 0$)$, possibly related to initial germination. The TSS concentration in L. campestris seeds (Figure 3c) exhibited the same pattern as the L.exaltatus seeds, decreasing in PG1 and PG6 throughout germination. The highest TSS concentration occurred in the control (397.28 $\left.\mathrm{mg} \mathrm{g}^{-1}\right)$. Similarly, the TSS decreased in pre-treated L. montanus seeds (Figure 3e) relative to the L. montanus control. The highest concentration of TSS was in the control treatment $\left(398.02 \mathrm{mg} \mathrm{g}^{-1}\right)$.

Reducing sugars $(R S)$. The Pearson's coefficients did not show a significant correlation between the RS concentration and PG or GR, with the exception of L. campestris (Table 2). In the three 


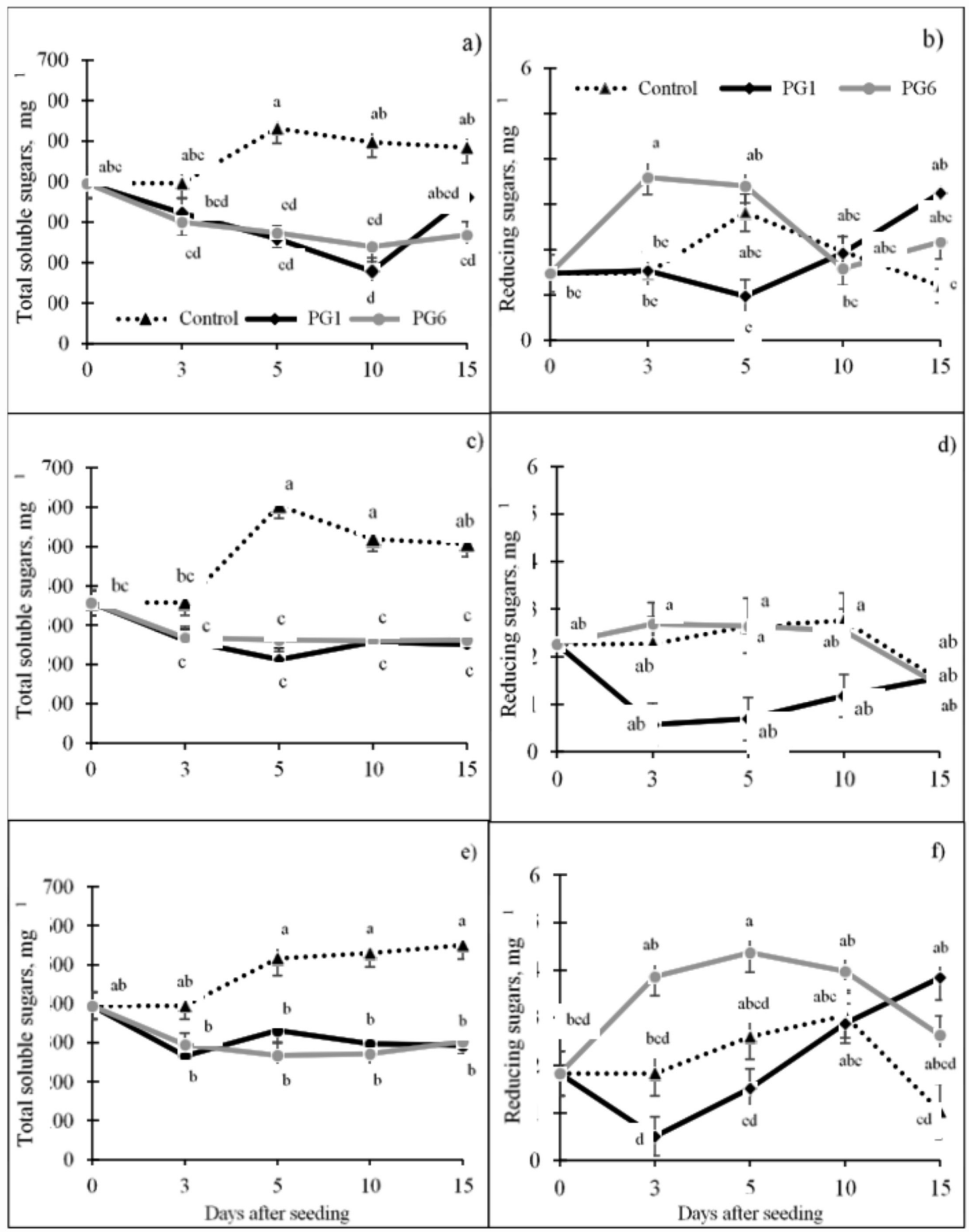

Figure 3. Effect of pre-germination treatments on the concentrations of soluble and reducing sugars (dry basis) of L. exaltatus (a, b), L. campestris (c, d) and L. montanus (e, f) seeds during germination Control: untreated seeds; PG1: $\mathrm{H}_{2} \mathrm{SO}_{4}$ for 15 min; PG6: wet sand at 80 ${ }^{\circ} \mathrm{C}$ for $1 \mathrm{~min}$. Different letters within treatments indicate significant differences $(P<0.05)$. 


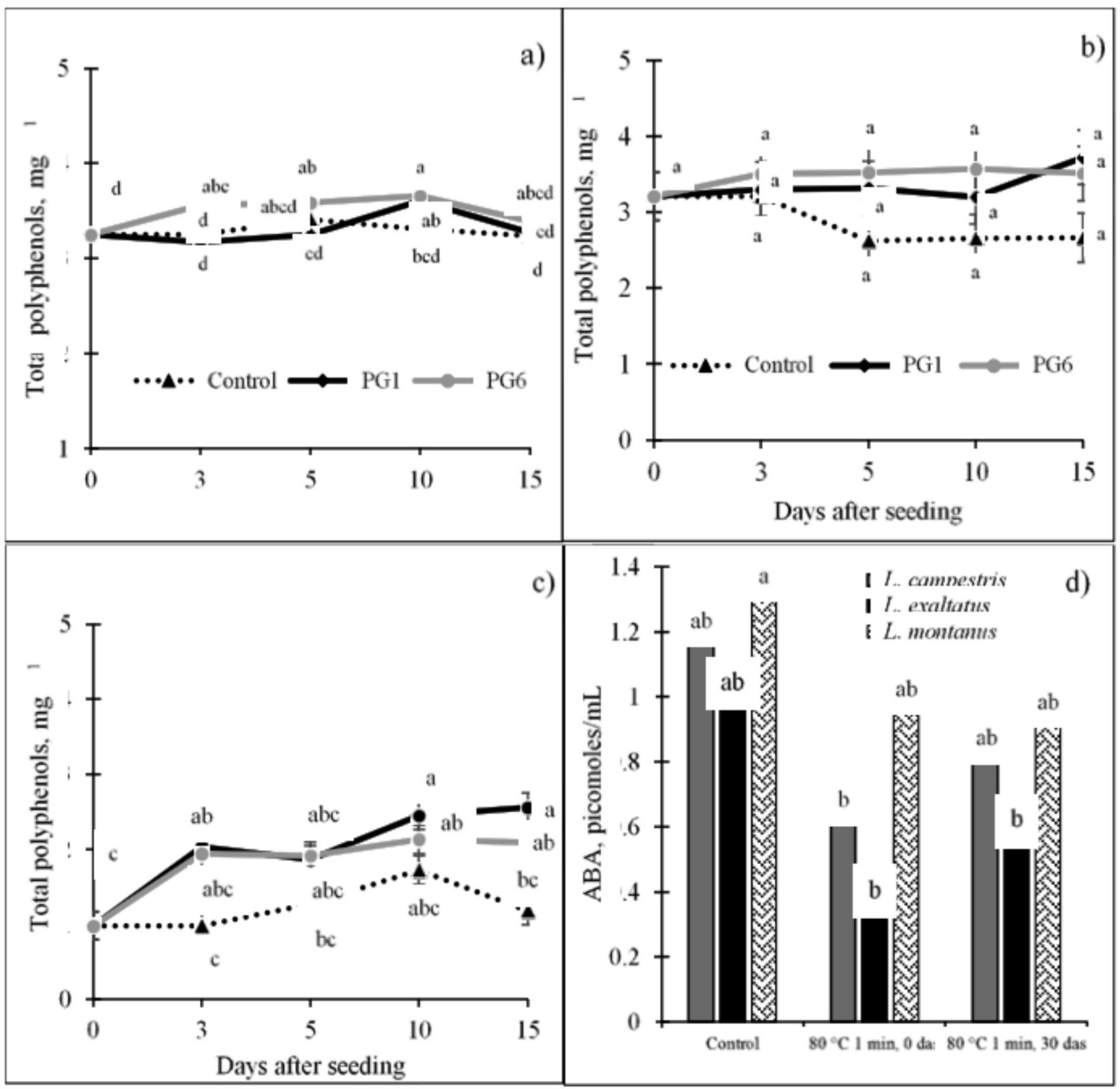

Figure 4. Effect of pre-germination treatments on total polyphenol concentration (dry basis) of L. exaltatus (a), L. campestris (b) and L. montanus (c) seeds, and on abscisic acid (ABA) concentration (d) during germination. Control: untreated seeds; $\mathrm{PG}_{1}: \mathrm{H}_{2} \mathrm{SO}_{4}$ for 15 min; PG6: wet sand at $80^{\circ} \mathrm{C}$ for $1 \mathrm{~min}$. das $=$ days after seeding. Different letters within treatments indicate significant differences $(P<0.05)$.

species, RS increased with PG6 and decreased with PG1 relative to the control (Figure 3). In the case of L. campestris (Figure 3d), the greatest decrease in the average RS concentration, relative to the control, was in PG1 (27\%). In contrast, under PG6, the RS concentration increased with germination time as did the control.

Total polyphenols (TPP). The concentration of phenolic compounds (Figure 4) was significantly affected by PG1 and PG6 in L. montanus, where a highly significant, positive correlation with GP was observed (Table 2). In this species (Figure 4c), a TPP increase of $114 \%$ at 10 das was observed relative to day 0 .

Abscisic acid $(A B A)$. To observe the behavior of ABA before and after the application of a treatment that increased germination, we evaluated the pre-germination treatment with water at $80{ }^{\circ} \mathrm{C}$ for $1 \mathrm{~min}$ (PG6). The concentration of ABA decreased with the application of PG6 in the three species, particularly in L. campestris and L. exaltatus (Figure 4d). L. montanus showed 
the highest ABA concentration (1.30 pmoles $\left.\mathrm{mL}^{-1}\right)$ in its seeds, followed by L. exaltatus $(0.97$ pmoles $\left.\mathrm{mL}^{-1}\right)$ and L. campestris $\left(0.77\right.$ pmoles $\left.\mathrm{mL}^{-1}\right)$. After the application of the treatment, at 30 das, the ABA concentration increased again in the three species, but it did not reach the levels found in untreated seeds $\left(1.3\right.$ pmoles $\left.\mathrm{mL}^{-1}\right)$.

\section{Discussion}

Percent germination and germination rate. The increase in the GP of the three species after the application of the pre-germination treatments, relative to the control, confirms the presence of physical dormancy in these seeds. In general, the three species responded favorably to the treatment with $\mathrm{H}_{2} \mathrm{O}$ at $80{ }^{\circ} \mathrm{C}$ for $1 \mathrm{~min}$ (PG6), which surpassed the treatment with sulfuric acid (PG1) in L. campestris and L. exaltatus. The GP response to PG6 differed among the species. On day 15, the GP was $69 \%$ for L. campestris, $41 \%$ for L. exaltatus and $36 \%$ for L. montanus. The efficiency of this treatment has also been observed in Lupinus lepidus seeds (Elliott et al. 2011) and in the seeds of other legumes such as L. leucaena cv. Cunningham, in which a GP of $55 \%$ was achieved for seeds exposed to water at $80{ }^{\circ} \mathrm{C}$ for $2 \mathrm{~min}$ (Sánchez et al. 2005). According to Tiryaki \& Topu (2014), thermal treatments such as abrupt changes in temperature cause the seed testa to crack because the cells expand in the hot water and then contract when exposed to ambient temperature.

The treatment with sulfuric acid was also able to break the seed dormancy of the species studied, although the germination percentages were lower than those reported for other Lupinus species, and in our study were GP values were even different for the same species from different regions of Mexico. With $12 \mathrm{~h}$ of exposure, $80 \%$ germination of $L$. varius seeds was obtained by Karaguzel et al. (2004) and with 90 min of exposure, a GP of $50 \%$ germination of L. campestris was achieved by Gutiérrez-Nava et al. (2010), whereas in L. montanus exposed for 15 min, a GP of $75 \%$ or $100 \%$ was obtained, depending on the origin of the seed (Acosta-Percástegui \& Rodríguez-Trejo 2005, Hernández-Ferretiz et al. 2008). In general, the application of $\mathrm{H}_{2} \mathrm{SO}_{4}$ increased GR in the three species studied as has been observed in other species. Although it has been mentioned that the application of strong acids increases germination by weakening the testa walls and permitting radicle protrusion, the acids can damage the embryo and produce abnormal seedlings if the concentration and exposure time are not appropriate (Kimura \& Islam, 2012).

The treatment with dry sand at $150{ }^{\circ} \mathrm{C}$ (PG5) inhibited the germination of L.exaltatus seeds, but did not inhibit $L$. campestris or L. montanus seeds. This suggests that after a fire event, $L$. exaltatus from region of the Serdán and Libres Valleys in Puebla would not germinate with subsequent moist conditions. Negative germination results were also reported by Robles-Díaz et al. (2014) for L. elegans and L. rotundiflorus seeds from the state of Jalisco, Mexico, when dry heat treatments were applied $\left(120\right.$ and $\left.150{ }^{\circ} \mathrm{C}\right)$. Variation in the species' response to these pretreatments among seeds from different regions was also manifest in the results of ZuloagaAguilar et al. (2011), who applied treatment PG5 on L. exaltatus collected in the state of Jalisco from an area prone to forest fires and achieved $93 \%$ germination. The negative effect observed in this study may have been due to rapid imbibition through the cracks produced by the treatment, causing the solid-state cell walls to pass through a liquid crystalline phase and become temporarily permeable (Schelin et al. 2003), affecting germination.

The variable responses observed among Lupinus seeds under study and those of the same species collected in different regions of Mexico, to the application of the same pre-germination treatment, could be explained by differences in the moisture content of the seeds at the moment of seed maturation. Baskin \& Baskin (2014) mentioned that when the moisture content of physically dormant seeds is $>14 \%$, they become permeable, but when the moisture content is $<10 \%$, physical dormancy persists even when the seeds are placed in a moist environment. Another explanation could be differences in the age of the seed, which could lead to harder seeds due to moisture loss during maturation or storage (Baskin \& Baskin, 2014).

Mobilization of reserves. According to the literature, it is in phase I of the germination process that the greatest mobilization of reserves occurs; among these reserves are proteins and sugars 
(Nonogaki et al. 2010, Bewley et al. 2013). During this phase, proteins are catabolized, which provides amino acids for the synthesis of de novo proteins to support seedling growth (Bewley et al. 2013). After the application of the treatments that increased the GP, both increases and decreases in protein concentration were observed during germination relative to the control in the species under study, but these changes were not related to the GP. In other species, however, increases in protein were observed after the application of a $\mathrm{H}_{2} \mathrm{SO}_{4}$ treatment (Benítez-Rodríguez et al. 2014). However, the application of treatments that included high temperatures $\left(50{ }^{\circ} \mathrm{C}\right)$ to break dormancy in Cucumis sativus L. seeds did not significantly affect the soluble protein concentration (Amritphale et al.2000).

The increase in the AA concentration in response to pre-germination treatments appears to be associated with GP. For the treatments in which the GP was high, there was an increase in the concentration of AA. Several authors have indicated that the increase in AA concentration during germination is due to protein degradation, which results in the release of AA. The reduction in the AA concentration, typically at 3 and 5 das in these three species, has also been observed in Arabidopsis thaliana seeds after the application of a scarification treatment at $4{ }^{\circ} \mathrm{C}$ and in Lens culinaris and Pisum sativum seeds (Joosen et al.2013, Rosental et al. 2014). In other species, an increase in the AA concentration during germination has also been observed (Kuo et al. 2004).

It was evident that the application of the pre-germination treatments reduced the soluble sugar content in the three species and that this decrease was associated with a high GP and GR. This decline in soluble sugars has been observed during the germination of Erythrina velutina Willd. (Ribeiro et al. 2012) and Lupinus luteus L. at $20^{\circ} \mathrm{C}$ (Zalewski et al. 2010) and during the release from dormancy of Malus domestica embryos treated with HCN (Bogatek et al. 1999). This reduction in soluble sugars in response to pre-germination treatments that promote germination, particularly PG1 and PG6, may be related to the initial activation of seed metabolism, which provides the energy for germination prior to the mobilization of reserves. However, the use of sugars varies depending on the species; they may be used during germination phase I and II or during radicle growth in phase III (Pritchard et al. 2002). The greatest decrease in RS in L. campestris, which occurred with treatment PG1, was related to the GP and GR, probably due to the high demand for energy by embryo growth. Moreover, the RS concentration under PG6 increased during the first 10 das, because the SS decreased in L. exaltatus and L. montanus, reflecting the mobilization and hydrolysis of the polysaccharides present in the seeds. These polysaccharides can be strongly hydrolyzed by hydrolases, which may be responsible for the incremental change in reducing sugars during germination (Rosental et al. 2014). It has also been observed that the application of pre-germination treatments, including hot water, to break dormancy in Oriza sativa seeds increase $\alpha$-amylase activity (Tung \& Serrano 2011). This enzyme hydrolyzes polysaccharides during germination to form simpler sugars, such that enzyme activities may be related to the increase in RS observed in the treatment with water at $80^{\circ} \mathrm{C}$ for 1 min (PG6).

Total polyphenols. During radicle protrusion, several biochemical processes are activated. These processes can change the composition of primary and secondary metabolites, which in turn can affect the activity of phenolic compounds (Xu et al. 2009). This increase in the average concentration of TPP with the $98 \% \mathrm{H}_{2} \mathrm{SO}_{4}$ for $15 \mathrm{~min}(\mathrm{PG} 1)$ and $\mathrm{H}_{2} \mathrm{O}$ at $80{ }^{\circ} \mathrm{C}$ for 1 min (PG6) treatments appears to be related to the GP in L. montanus seeds. Different researchers have described an incremental change in TPP concentration during the seed germination process of Vigna radiata, Avena nuda, Cicer arietinum, L. campestris, and Chenopodium quinoa (Troszynska et al. 2006, Xu et al. 2009, Tarzi et al. 2012, Jiménez-Martínez et al. 2012, Carciochi et al. 2014). Cevallos-Casals \& Cisneros-Zevallos (2010) also found an increase in the phenolic compound content in seeds of 13 species including mungbean, alfalfa, fava, fenugreek, mustard, wheat, broccoli, sunflower, soybean, radish, kale, lentil and onion, during the passage from dormancy to non-dormancy. According to López-Amorós et al. (2006), the increase in TPP is related to the activation of hydrolase and polyphenoloxidase enzymes, which increase their activity during germination.

Abscisic acid. The decrease in ABA observed after the application of the heat treatment (PG6) is related to the GP and the hormone balance ratio between ABA and gibberellins (Bewley et 
al. 2013). ABA acts as a regulator of germination, inhibiting it at high concentrations (Toh et al. 2008). This decrease in ABA has been observed in Arabidopsis seeds in response to a heat treatment at $34{ }^{\circ} \mathrm{C}$ (Toh et al. 2008). A similar decrease in ABA was observed in Hordeum distichon $\mathrm{cv}$ Triumph seeds after applying a treatment with $\mathrm{H}_{2} \mathrm{SO}_{4}$ to break dormancy (Wang et al. 1998).

In general, the results showed that the seeds of the three species under study responded to treatment with moist heat at $80{ }^{\circ} \mathrm{C}$ for 1 min by increasing germination, the concentration of amino acids and reducing sugars, and decreasing soluble sugars.

\section{Acknowledgements}

The first author thanks CONACYT for the scholarship they granted. The study was funded by CONACYT project CB-2012-01 181428, and by COLPOS project CPCT-467. We thank the anonymous reviewers whose accurate observations help to improve and enrich this manuscript.

\section{Literature cited}

Acosta-Percástegui J, Rodríguez-Trejo DA. 2005. Factors affecting germination and pregerminative treatments of Lupinus montanus seeds. Interciencia 30: 576-579.

Ali HH, Tanveer A, Nadeem MA, Asghar HN. 2011. Methods to break seeds dormancy of Rhynchosia capitata, a summer anual weed. Chilean Journal of Agricultural Research 71: 483-487. DOI:10.4067/ S0718-58392011000300021

Amritphale D, Sreenivasulu Y, Singh B. 2000. Changes in membrane fluidity and protein composition during release of cucumber seeds from dormancy by a higher temperature shift. Annals of Botany $\mathbf{8 5}$ : 13-18. DOI: $10.1006 /$ anbo.1999.0992

Baskin CC. 2003. Breaking physical dormancy in seeds - focussing on the lens. New Phytologist 158: 229232. DOI:10.1046/j.1469-8137.2003.00751.x

Baskin CC, Baskin JM. 2014. Germination ecology of seeds with physical dormancy. In: Baskin CC, Baskin JM, eds. Seeds: Ecology, Biogeography, and Evolution of Dormancy and Germination. San Diego: Academic Press, 145-185.

Baskin JM, Baskin CC. 2004. A classification system for seed dormancy. Seed Science Research 14: 1-16. DOI:10.1079/SSR2003150.

Benítez-Rodríguez A, Gamboa-deBuen M, Sánchez-Coronado E, Alvarado-López S, Soriano D, Méndez I, Vázquez-Santana S, Carabias-Lillo J, Mendoza A, Orozco-Segovia A. 2014. Effects of seed burial on germination, protein concentration and seedling survival in Dodonaea viscosa. Plant Biology 16: 732-734. DOI:10.1111/plb.12110.

Bewley JD, Bradford KJ, Hilhorst HWM, Nonogaki H. 2013. Seeds: Physiology and Dormancy. New York: Springer.

Bogatek R, Côme D, Corbineau F, Picard M-A, Zarska-Maciejewska B, Lewak S. 1999. Sugar metabolism as related to the cyanide-mediated elimination of dormancy in apple embryos. Plant Physiology and Biochemistry 37: 577-585. DOI: 10.1016/S0981-9428(00)80110-2.

Carciochi RA, Manrique GD, Dimitrov K. 2014. Changes in phenolic composition and antioxidant activity during germination of quinoa seeds (Chenopodium quinoa Wild.) International Food Research Journal 21: 767-773.

Cevallos-Casals BA, Cisneros-Zevallos L. 2010. Impact of germination on phenolic content and antioxidant activity of 13 edible seed species. Food Chemistry 119: 1485-1490. DOI:10.1016/ j.foodchem .2009 .09 .030

Elliott CA, Fischer DG, LeRoy CJ. 2011. Germination of three native Lupinus species in response to temperature. Northwest Science 85: 403-410. DOI:10.3955/046.085.0223

Gutiérrez-Nava P, De León González F, Etchevers Barra J, Casas-Fernández A. 2010. Effect of scarification, self-inhibition, and sowing depth on seed germination of Lupinus campestris. Chilean Journal of Agricultural Research 70: 365-371. DOI:10.4067/S0718-58392011000300021

Hernández-Ferretiz E, Rivera-Meléndez RK, Ramos-Herrera OJ, Salinas-Pérez FC, Rodríguez-Monroy M, Bermúdez-Torres K. 2008. Effect of scarification treatments on germination of Lupinus montanus HBK seeds. In: Palta JA, Berger JB, eds. 2008. Lupinus for Health and Wealth. Proceedings of the 12th International Lupin Conference. Fremantle: International Lupin Association, Canterbury, 405-409 p.

Jiménez-Martínez C, Cardador-Martínez A, Martínez-Ayala AL, Muzquiz M, Martin-Pedrosa M, DavilaOrtiz G. 2012. Changes in protein, nonnutritional factors, and antioxidant capacity during germination of L. campestris seeds. International Journal of Agronomy 2012. DOI:10.1155/2012/387407. 
Joosen RVL, Arends D, Li Y, Willems LAJ, Keurentjes JJB, Ligterink W, Jansen RC, Hilhorst HWM. 2013. Identifying genotype-by-environment interactions in the metabolism of germinating Arabidopsis seeds using generalized genetical genomics. Plant Physiology 162: 553-556. DOI:10.1104/pp.113.216176.

Karaguzel O, Cakmakci S, Ortacesme V, Aydinoglu B. 2004. Influence of seed coat treatments on germination and early seedling growth of Lupinus varius L. Pakistan Journal of Botany 36: 65-74.

Khadri M, Tejera NA, Lluch C. 2006. Allevation of salt stress in common bean (Phaseolus vulgaris) by exogenous abscisic acid supply. Journal of Plant Growth Regulators 25: 110-119. DOI: 10.1007/ s00344-005-0004-3.

Kimura E, Islam MA. 2012. Seed scarification methods and their use in forage legumes. Research Journal of Seed Science 5: 38-50. DOI: 10.3923/RJSS.2012.38.50.

Kishwar A, Guijar RS, Niwas R, Gopal M, Tyagi A. 2011. A rapid method for estimation of acid and characterization of ABA regulated gene in response to water deficit stress from rice. American Journal of Plant Physiology 6: 144-156. DOI:10.3923/ajpp.2011.144.156.

Kuo YH, Rozan P, Lambein F, Frias J, Vidal-Valverde C. 2004. Effects of different germination conditions on the contest of free protein and non-protein amino acids of commercial legumes. Food Chemistry 86: 537-545. DOI:10.1016/j.foodchem.2003.09.042.

López-Amorós ML, Hernández T, Estrella I. 2006. Effect of germination on legumes compounds and their antioxidant activity. Journal Food Composition and Analysis 19: 227-283. DOI:10.1016/ j.jfca.2004.06.012.

Lowry OH, Rosebrough NJ, Farr AL, Randall RJ. 1951. Protein measurement with folin phenol reagent. Journal of Biological Chemistry 193: 265-275. DOI:[R9]

Nonogaki H, Bassel GW, Bewley JD. 2010. Germination- still a mystery. Plant Science 179: 574-581. DOI:10.1016/j.plantsci.2010.02.010.

Pritchard SL, Charlton WL, Baker A, Graham IA. 2002. Germination and storage reserve mobilization are regulated independently in Arabidopsis. The Plant Journal 31: 639-647. DOI: 10.1046/j.1365313X.2002.01376.X.

Qihe Y, Xiaojuan Y, Wanhui Y. 2006. Dormancy mechanism and breaking methods for hard seeds. Chinese Bulletin of Botany 23: 108-118. DOI:10.17129/botsci.18.

Ribeiro RCR, França BD, Pelacani CR. 2012. Mobilization of reserves and germination of seeds of Erythrina velutina Willd. (Leguminosae - Papilionoideae) under different osmotic potentials. Revista Brasileira de Sementes 34: 580 - 588. DOI: 10.1017/S0960258515000070.

Robles-Díaz E, Jurado E, Ruiz-López E, Yáñez-Espinosa Y, Flores J. 2014. Heat shock effect in breaking physical dormancy in seeds of Lupinus elegans and L. rotundiflorus from Jalisco, México. Botanical sciences 92 (1): 123-129. DOI: 10.17129/botsci.18.

Rosental L, Nonogaki H, Fait A. 2014. Activation and regulation of primary metabolism during seed germination. Seed Science Research 24: 1-15. DOI:10.1017/S0960258513000391.

Sánchez JA, Reino J, Muñoz B, González Y, Montejo L, Machado R. 2005. Efecto de los tratamientos de hidratación-deshidratación en la germinación, la emergencia y el vigor de plántulas de Leucaena leucocephala cv. Cunningham. Pastos y Forrajes 28: 209-220.

SAS Institute. 2010. SAS System for Windows, Release 9.3, SAS Institute, Cary, North Carolina, USA.

Satyanarayana B, Subhashinidevi P, Arundhati A. 2011. Biochemical changes during seed germination of Sterculia urens Roxb. Notulae Scientia Biologicae 3: 105-108. DOI:10.15835/nsb336116.

Schelin M, Tigabu M, Ericksson I, Sawadogo L. Odén PC. 2003. Effects of scarification, giberelic acid and dry heat treatments on the germination of Balanites aegyptica seeds from the sudani savanna in Burkina Faso. Seed Science \& Technology 31: 605-617. DOI:10.15258/sst.2003.31.3.10.

Shen-zuo F, Jia-yuang W. 2007. Changes in biochemical composition and enzyme activity during dormancy release of Cyclocarya paliurus seeds. Forestry Studies in China. 9: 7-13. DOI:10.1007/s11632007-0002-6.

Somogy, M. 1952. Notes on sugar determination. Journal of Biological Chemistry 195: 19-23.

Sussulini A, García JS, Mesko MF, Moraes DP, Flores EMM, Pérez CA, Arruda MAZ. 2007. Evaluation of soybean seed protein extraction focusing on metalloprotein analysis. Microchimica Acta 158: 173-180. DOI:10.1007/s00604-006-0678-7.

Tarzi BG, Gharachorlooa M, Bahariniab M, Mortazavic SA. 2012. The effect of germination on phenolic content and antioxidant activity of chickpea. Iranian Journal of Pharmaceutical Research 11(4): $1137-$ 1143 .

Tiryaki I, Topu M. 2014. A novel method to overcome coat-imposed seed dormancy in Lupinus albus L. and Trifolium pratense L. Journal of Botany. Article ID 647469. DOI: 10.1155/2014/647469.

Toh S, Imamura AA, Watanabe K, Nakabayashi M, Okamoto Y, Jikumaru A, Hanada Y, Aso K, Ishiyama N, Tamura S, Luchi M, Kobayashi S, Yamaguch I, Kamiya Y, Nambara E, Kawakam N. 2008. High temperature-induced abscisic acid biosynthesis and its role in the inhibition of gibberellin action in Arabidopsis seeds. Plant Physiology 146: 1368-1385. DOI: 10.1104/pp.107.113738. 
Received:

August 26th, 2016

Accepted:

November 15th, 2016
Tonguc M, Elkoyunu R, Erbas S, Karakurt Y. 2012. Changes in reserve composition during germination and initial seedling development of safflower (Carthamus tinctorius L.). Turkish Journal of Biology 32: 107-112. DOI: 0.3906/biy-1012-164.

Troszynska A, Agnieszka W, Narolewska O. 2006. Effect of germination time on the content of phenolic compounds and sensory quality of mung bean (Vigma radiate L.) sprouts. Polish Journal of Food Nutrition Science 56: 453-459.

Tung LD, Serrano EP. 2011. Effects of warm water in breaking dormancy of rice seed. Omonrice 18: 129-136.

Wang M, Van der Meulen RM, Visser K, Henk-Peter VS, Van Duijn B, Boer AH. 1998. Effects of dormancy-breaking chemicals on ABA levels in barley grain embryos. Seed Science Research 8: 129-137. DOI: $10.1017 / \mathrm{S} 0960258500004025$

Xu JG, Tian CR, Luo JY, Wang XD, Tian XD. 2009. Dynamic changes in phenolic compounds and antioxidant activity in oats (Avena nuda L.) during steeping and germination. Journal of Agricultural Food Chemistry 57: 10392-10398. DOI: 10.1021/jf902778j.

Yemm EW, Cooking JK. 1995. The Estimation of carbohydrates in plant extracts by Anthrone. Biochemical Journal 57: 508-5. DOI[R16]:

Zalewski K, Nitkiewicz B, Lahuta LB, Glowacka K, Socha AA, Amarowicz R. 2010. Effect of jasmonic acid-methyl ester on the composition of carbohydrates and germination of yellow lupine (L. luteus L.) seeds. Journal of Plant Physiology 167: 967-973. DOI:10.1016/j.jplph.2010.01.020.

Zuloaga-Aguilar S, Briones O, Orozco-Segovia A. 2011. Seed germination of montane forest species in response to ash, smoke and heat shock in Mexico. Acta Oecologica 37: 256-262. DOI:10.1016/ j.actao.2011.02.009. 